The Labore Journal of Economics

11 : 1 (Summer 2006) pp. 99-119

\title{
Bonded Labor in the Brick Kiln Industry of Pakistan
}

\section{Muhammad Javaid Iqbal"}

\begin{abstract}
Bonded labor is a dominant feature of the brick kiln industry of the country. Apparently an outcome of poverty, it is closely linked to the socio-cultural fabric of society. The vicious cycle of bondage subjugates the families physically and economically so that they are unable to break out of the trap despite putting in hard labor. The issue has a number of socioeconomic implications and its solution lies in a multi pronged strategy; economic uplift, social involvement and educational breakthrough of the bonded families. The paper explores the nature and extent of bonded labor in the brick kiln sector and analyzes its repercussions on children and women of the bonded families. It also examines the available legal infrastructure tackling bonded labor. Finally the paper proposes a comprehensive scheme to ameliorate the concerns of bonded families and ways to eradicate the menace from the industry.
\end{abstract}

\section{Introduction}

Brick making is one of the most ancient industries, the craft is as old as that of the Indus Valley Civilization (2500-1500 BC). Fired bricks were also used by the ancient people of the civilizations of Egypt and Mesopotamia for building tombs and temples. Although the design, shape and weight of bricks have undergone numerous historical changes, the production technology has experienced very limited changes. Bricks are prepared, processed and baked at the brick kiln. Being situated in the remote country side, the brick kiln industry portrays a unique model of industrial relations ${ }^{1}$. The organization of

\footnotetext{
* The author is Joint Director, Labor Welfare in the Labor and Human Resource Department, Government of the Punjab. The views expressed in the article are his own and do not necessarily represent those of the Department.

${ }^{1}$ Bipartism and Tripartism are two main models of industrial relations. In Bipartism workers and management are two major actors whereas Tripartism also involves a third party i.e., the government. However, the Traditional Model of industrial relations in the brick kilns comprises four major actors i.e., owner, jamadar, pathera and government. The workers are weak, fragmented and disorganized. Sociocultural forces play a dominating role in the Traditional Model.
} 
work is highly influenced by socio-cultural factors. Migrants in general and traditional "low-caste" family labor in particular, continue to characterize labor in the brick kilns. Even though Muslims make up a majority of the workforce, Christians also supply a significant proportion of "pathera" family labor, especially in the Punjab. Generally poor in nature, all categories of kiln labor, both salaried workers such as "jalai walas" ${ }^{3}$ " and piece-rated labor take substantial advances, both at the time of joining a kiln as well as subsequently. Advances (peshgi) ${ }^{4}$ taken amount to loans because of high interest charges, manipulation of books and low wages. The families become virtual prisoners of the owner and are subject to physical, economic and social exploitation. The clutches of debt are so severe that the families can not get themselves out of the debt for generations in spite of the hard work they put in by even engaging their women and children.

The "peshgi" system of debt bondage is hundreds of years old in Pakistan. Rooted in the feudal relationship of landlords and peasants it blends some of the worker-owner relations of feudalism with the economics of modern capitalism to create a kind of bondage, halfway between the old and the new. Along with the brick kilns, the system is generally in vogue in agriculture, fisheries, mining, glass bangle-making, and carpet weaving. The present government in collaboration with the ILO is pooling significant resources for the elimination and rehabilitation of bonded labor from all those sectors. Various NGOs are also active in exploring their role. The issue has a number of socio-economic implications and its solution does not lie in any single strategy but in economic uplift, social involvement and educational breakthrough of the bonded families. The need therefore is to devise a comprehensive strategy which should not only cover all aspects of the problem but would also have a sustainable solution. Relying on secondary sources, this paper is an effort to explore the nature and extent of bonded 1abor, its socio-economic implications and repercussions on children and women. The available legal remedial measures for tackling the issue of bonded labor are examined in Section 5. The role of trade unions and NGOs has also been highlighted. In the end, the paper proposes a 'model' for eradication of the menace of bonded labor from the brick kiln industry.

\footnotetext{
${ }^{2}$ Patheras are piece-rate workers involved in brick making. They constitute the 'junk' of the brick kiln labor force. They are migratory in nature, receive advances and are victims of the Bonded Labor System and thus are the focus of the present study.

${ }^{3}$ Jalaiwala is a brick kiln worker involved in the control of fire in the kiln. He is also called a 'mistari'.

${ }^{4}$ Peshgi is advance received by the brick kiln workers before he actually starts his work. Advances are also taken afterwards.
} 


\section{Conceptualization of Bonded Labor}

The term "bonded labor" refers to workers who render services under conditions of bondage arising from economic considerations, notably through a loan or advance. Where debt is the root cause of bondage, the implication is that the worker (and their dependants or heirs) is tied to a particular creditor for a specified or unspecified period until the loan is repaid (ILO, 2001:32). It is a systemized feature prevailing in certain sectors of society wherein advances are common and no work can be done without advance or "Peshgi". The Bonded Labor (Abolition) Act, 1992 puts it in the following way:

The "Bonded Labor System" implies the system of forced, or partly forced labor under which a debtor enters or has, or is presumed to have, entered into an agreement with the creditor to the effect that, --

a) in consideration of advance (peshgi) obtained by him or by any of the members of his family (whether or not such advance (peshgi) is evidenced by any document) and in consideration of the interest, if any, due on such advance (peshgi), or

b) in pursuance of any customary or social obligations, or

c) for any economic consideration received by him or any of the members of his family;

be would

(1) render, by himself or through any member of his family, or any person dependent on him, labor or service to the creditor, or for the benefit of the creditor, for a specified period or for an unspecified period, either without wages or nominal wages, or

(2) forfeit the freedom of employment or adopt other means of livelibood for a specified period or for an unspecified period, or

(3) forfeit the right to move freely from place to place, or

(4) forfeit the right to appropriate and to sell at market value any of his property or product of his labor or the labor of members of his family or any person dependent on him, and includes the system of forced, or partly forced labor under which a surety for a debtor enters, or has or is presumed to have, entered, into an 
agreement with the creditor to the effect that, in the event of the failure of the debtor to repay the debt, he would render the bonded labor on behalf of the debtor.'

\section{In Search of Literature}

The incidence of bonded labor in brick kilns has been highlighted by many writers. Thomas (1995) while identifying urban and rural labor market segmentation has pointed out bonded labor as a main characteristic of rural labor markets. He termed it as an extreme form of labor exploitation in South Asia. Ercelawn (2004), Hussain (1990), Hamid (1993), Mitha et. al. (1989), ILO (2001), Bales (1998), Kemal (1994); all pointed out the existence of advances, "peshgi", indebtedness and bondage in the brick kiln sector of Pakistan. The ILO (1998), through a survey confirms that $93 \%$ of the brick kiln workers received advances before they started working. The studies conclude that large family size is an important factor contributing to loans. The debt usually piled up and could not be paid by the indebted families, thus carried over to generations as 'eternal' debt ${ }^{6}$. There is also no dispute regarding the involvement and exploitation of women and children at the workplace. Sexual abuse, torture and beating at the brick kilns have also been reported ${ }^{7}$. To the ILO (1998), large family size, mounting financial constraints and lack of educational facilities at or near the brick kilns induce the parents to use children as help during brick making. Too much work by the children at the brick kilns poses a great threat to their physical, mental, intellectual, moral and psychological growth. To Bale, "if the conditions of work are not bad enough, the system of working in the brick kilns presents other dangers and hardships. Virtually all of the families making bricks are working against a debt owed to the owner of the kiln. These debts pose a special danger to the children. Sometimes, when a kiln owner suspects that a family will try to run away and not pay off their debt, a child might be taken hostage to force the family to stay and work" (Bales, 1998). Mitha et. al. (1989) pointed out that women work even during pregnancy, and 'they work till they actually go into labor'.

\footnotetext{
${ }^{5}$ It is contained in the Preamble of the Bonded Labor System (Abolition), Act 1992.

${ }^{6}$ The meager amount of debt in the bonded labor system pile up due to high interest rate and wrong accounting and thus cannot be paid by the families even by putting in generations of labor.

${ }^{7}$ Human Rights Commission of Pakistan in its report "State of Human Rights in 2004" has pointed out occurrences of such incidences at the brick kilns. Some other writers like Ercelawn have also indicated such an abuse but, according to him, it is very difficult to come by information on sexual abuse during surveys due to socio-cultural implications unless it is highlighted in the press.
} 
Poverty is emphasized as being the root cause for accepting advances by the families of brick kiln workers and trapping themselves into bondage. It is also contended that contracts of bondage are accepted due to uncertainty, lack of stability in employment and absence of any social safety nets in Pakistan. To Bales "slavery is hidden behind contracts; and slavery flourishes in communities under stress. It does not thrive in western countries where people have a reasonable standard of living and financial security. Slavery grows best in extreme poverty" (Bales, 1998). He further stresses that if there were security of employment in Pakistan, or some provision for a living wage, no family would have chosen to work in the "peshgi" system. Another important aspect about the advances is that they are not only taken at the start but continue in a systemized manner, since laborers need it due to emergencies, illness, marriages etc $^{8}$; as owners prefer to term subsequent "friendly loans" (Ercelawn, 2004). False accounting and high interest on the loans aggravate the situation and the families find it difficult to pay off the debt even after putting in hard labor.

As far as the origin of the bonded labor system is concerned, some analysts associate bonded labor with traditional patterns of land-ownership, including the caste-based or personally bonded labor which is secured by debt, and which can frequently extend across generations. Others argue that bonded labor has also been a feature of recent trends in commercial agriculture, of both small and large scale, involving the debt-based attachment of casual and migrant workers. The brick-making labor comprises few castes such as, “Masalies", “ $\operatorname{Odd}^{10}$ ”, Christian and Afghani; they are all poor and have low status in society. The bonded labor system can also be linked to socio-cultural division of labor (professions) prevalent in the Sub-Continent for centuries. Migratory in nature, the labor retain unique features. Ercelawn (2004) referred to it as "footloose" labor". The institution of "jamadar", as contended by Hamid (1993), Mitha et. al. (1989), ILO (2001), Bales (1998), Kemal (1994), and Ercelawn (2004), plays a pivotal role in the "peshgi" system. Jamadars do not only provide a link between labor and the brick kiln owners, as explained by Mitha et. al., but

8 Rites, customs, births, deaths, engagements, and marriages are celebrated in the traditional manner by spending lavishly both time as well as money. Labor has to take more advances for such functions. The loans mount and become eternal debt.

${ }^{9}$ Masalies are new Muslims, belonging to low status caste in the central and southern

Punjab.

${ }^{10}$ Odd are nomads or gypsies.

${ }^{11}$ The term "Footloose Labor" might have been taken from Johns Breman, who used it in his work on migratory agriculture labor in Southern India. The brick kiln workers in a Bonded Labor System are not "loose". They on the other hand cannot move due to debt boundage, the term therefore does not seem proper for brick kiln workers. 
are also the main source of bonded labor by acting as guarantor "zamin" for the bonded laborer.

As far as the tackling of the issue of bonded labor is concerned, affordable credit, according to many, would weaken the linkage between debt and labor. Such a strategy may be useful in agriculture, fisheries, carpet weaving or bangle making where the worker can start an independent business. According to Ercelawn and Mitha mere enforcement of existing 1abor laws particularly the Minimum Wage Ordinance, Bonded Labor System (Abolition) Act and Factories Act, will have mitigating effects. They, however, stress the need for organizing bonded labor and recommend an active role of the NGOs in the efforts for abolition and rehabilitation of bonded labor. The Brick Kiln Owners Association, on the other hand, is seriously thinking about the introduction of molding machines to replace brick making workers ${ }^{12}$.

\section{Nature and Extent of Bonded Labor in the Brick Kilns}

The network of brick kilns is widespread to the extent that all the urban and rural areas have brick kilns. About $90 \%$ of brick kilns function in rural locations. The obvious reason is availability of cheap land, proximity of roads for the transportation of fuel and bricks, proximity of markets for bricks and low paid workforce. The PILER ${ }^{13}$ identified that as many as $5000^{14}$ brick kilns are concentrated in the province of the Punjab and around 6000 in the country. On the other hand, Bale (1998), estimated that there are approximately 7000 brick kilns in the country. Large population, widespread prosperity, continuing high public investment in infrastructure, plentiful clay, fine sand and water, and a large pool of landless labor according to Ercelawn (2004) are important features and account for the concentration of brick kilns in the Punjab. On the basis of 15 families at each brick kiln with 6 to 8 persons average family size ${ }^{15}$, they roughly estimated that 150,000 to 200,000 families and

\footnotetext{
${ }^{12}$ Modern brick making machine work is ten times faster than the present system and even a smaller kiln can make 40,000 bricks in a day, i.e. almost double than that of the present system. The cost of the machinery is high thus beyond the reach of Pakistani kiln owners. It also does not suit the labor abundant economy of Pakistan.

${ }^{13}$ Pakistan Institute of Education and Research, Karachi.

${ }^{14}$ Whereas according to the Labor Department, 2449 brick kilns in the province have so far been reported by 31st August 2005, and of these 1132 have been registered under the Factories Act, 1934.

${ }^{15}$ Normal family size is high amongst the brick kilns workers. A team of ILO experts visited a brick kiln near Lahore during 2000. The writer also accompanied the team. The team met with an individual who had 22 children from his two wives. He was illiterate and was even unable to remember the names of all his children.
} 
around 750,000 to 900,000 person workforce is engaged directly in the brick kiln sector.

Brick making is a simple process, the soil is mixed with water and kneaded into dough which is cast into moulds and shaped as bricks which are dried in the open place and finally are stalked into the kiln. The sundried bricks are converted to red bricks in the kiln. Brick making is labor intensive work requiring little skill. The semi-skilled workers (patheras) involved for the purpose are characterized as contractual family labor working under the bonded labor system. Recruitment is indirect, through a contractor or subcontractor (jammadar), who receives commission from the workers. The contractor also channel advances, and is responsible for the 1aborer's work and debt-servicing. Most of the time he is a co-worker and sometimes is also a relative of the labor. The brick kiln workers are offered advances (peshgi) through contractors before the work is actually commenced. An informal contract is made between the head of the family (who usually is male) with the brick kiln owner and also is witnessed by the contractor. The head of the family involves most of his family members including males, adolescents, children and women for the preparation of the bricks. Working hours are flexible and families work from dawn to sunset. Brick making is piece rated work, thus the workers are paid on the basis of the number of bricks they or their family prepared ${ }^{16}$. Payment is made on a weekly basis i.e., on every Thursday through the contractor who also deducts his $5 \%$ commission. Deductions in connection with loans and advances are also made at the same time. Fresh loans are also offered during the course of work and the cycle continues till the workers are completely trapped. It is very difficult for the families to get rid of the debt. Only a few families can manage to get ahead of the game and reduce their debt. This is most likely in a year when a family's children are old enough (12 to 15 years) to work as hard as the adults; the weather is good, and no accidents or illnesses occur. Illness can be a catastrophe. Life events, like weddings, funerals, arrest of a relative, an accident, heavy rains, or anything else that brings extra expenses increase the family debt.

Brick making is a semi-skilled and monotonous job. The craft like other professions ${ }^{17}$ travels through generations within the families. Children of the bonded families learn the craft from their parents and continue the profession of their ancestors as their means of livelihood. They actually have

\footnotetext{
${ }^{16}$ The minimum wage rate for each one thousand bricks, as notified by the government is Rs.184.

${ }^{17}$ It is just like societal division of professions in the sub-continent i.e., cobblers, weavers, water carriers, blacksmiths, hair dressers etc.
} 
to remain in the same profession as they will have to pay off the 'eternal debt' owed by their family due to their parents or parents of their parents. Limited horizontal mobility exists due to migration, however hardly any vertical mobility was seen due to debt and socio-cultural circumstances ${ }^{18}$.

The labor resides at the kiln in the houses constructed and owned by the owner. These localities lack basic amenities of life such as drinking water, sanitation etc. There hardly exists any schools near those vicinities. The workers live in isolation from the local population with their own culture, traditions and customs. Isolation from the local populace gives rise to crimes such as theft and gambling which are common. Family size is large and the dependency ratio is very high. The low earnings are not enough to meet the requirements of large families. The families are caught in the vicious cycle of poverty and cannot afford even elementary education for their young ones. They lack initiatives and have no potential to migrate to urban areas for higher rewards due to indebtedness and socio-cultural norms. Children and women, being the most vulnerable segment, have to bear the brunt of the burden.

\subsection{Child Labor}

The children of the working community have no choice but to work alongside their families. They are usually assigned lighter tasks such as helping in the kneading of mud, carrying of pieces of mud to the adult workers, spreading sand on the wet side and assisting in watering the soil for mud making. They also bring food and drinking water to the adult workers.

Estimates made by UNICEF show that at least 250,000 children work in brick kilns. It is also estimated that two-fifths to two-thirds of the total working children are in the brick kiln industry and most of them are bonded (Kemal, 1994:16). Poverty, in general, and non availability of schooling facilities at or near the brick kilns, in particular, is the major reason for low literacy rate amongst the children of brick kiln workers. Unfortunately, if schools exist in the vicinity and the children of the brick kiln workers are enrolled, they cannot continue studies due to the migration of their parents.

Large family size is an important factor contributing to loans and sustaining child labor in the brick kiln sector. Child rearing and child caring are missing due to poverty. The parents generally believe (Mitah et. al., 1989)

\footnotetext{
${ }^{18}$ Vertically it is not possible to break the boundaries of the bonded system due to non availability of alternative work and absence of educational opportunities for the children of the brick kiln workers.
} 
that "the children of the poor grow up by themselves". The indebtedness occurring through the "pesghi" system locks the working families into a dependency relationship and children being the most vulnerable always suffer more. In the virtual imprisonment of the 'owner' as well as of their parents the children have to work in very harsh weather, for insignificant economic gains and for extremely long working hours ${ }^{19}$.

\subsection{Conditions of Female Workers}

Women make a significant contribution through family kiln labor across Pakistan ${ }^{20}$. They are usually found in the brick fields involved in the making of mud bricks. As advances are binding on the entire family, women being the most vulnerable are the worst affected. They have to work even during pregnancy. Alongside putting in this hard labor they have to do family chores, like preparing food for all the family, collect wood for the fire, bringing water, washing clothes and arranging fodder for the buffaloes or cows, goats etc. They also have to take care of the sick and elderly of the family $^{21}$. Women are even exposed to sexual harassment if their male head of family runs away from the brick kiln.

\section{Available Legal Infrastructure}

This section examines the available legal framework for tackling the issue of bonded labor in the brick kiln sector.

\subsection{International Commitments}

"No one shall be held in slavery or servitude."

\section{(Universal Declaration of Human Rights Article- 4)}

All work or service which is exacted from any person under the menace of any penalty and for which the person has not offered her or himself voluntarily is compulsory or forced labor and has been covered under the ILO Forced Labor Convention, 29 (1930) and Abolition of Forced

\footnotetext{
${ }^{19}$ Summer is considered to be the most favorable time for brick making, because, firstly, the days from May to July are comparatively longer which suit both the labor and the drying of bricks. Secondly, it is followed by the rainy monsoon season during which demand as well as price of bricks rise, so this is a peak time for the brick kiln owner to extract maximum surplus from all the members of the bonded family.

${ }^{20}$ Unfortunately, women like children and adolescents are rarely, if ever, directly acknowledged as labor i.e. to receive advances and compensation.

${ }^{21}$ On average every bonded family has at least one old or sick person.
} 
Labor Convention, 105 (1957). The ratifying States are bound to eradicate forced labor in all its forms including bonded labor.

\subsection{The Constitution of the Islamic Republic of Pakistan}

The Constitution of the Islamic Republic of Pakistan prohibits all forms of exploitation of its citizens.

"The State shall ensure the elimination of all forms of exploitation and the gradual fulfillment of the fundamental principle, from each according to his ability, to each according to his work" (Article-3).

There is no place for Bondage; "slavery is non-existent and forbidden and no law shall permit or facilitate its introduction to Pakistan in any form. All forms of forced labor and traffic in human beings are probibited. No child below the age of 14 years shall be engaged in any factory or mine or any other hazardous employment" (Article 11 (1-3).

\subsection{Bonded Labor System (Abolition) Act 1992}

Bonded Labor System (Abolition) Act, 1992 is a special law dealing with bonded labor. The law prohibits all forms of advances or "peshgi" and forced and bonded labor resulting there under.

"And whereas it is necessary to provide for abolition of bonded labor system with a view to preventing the economic and physical exploitation of the labor class in the country and for matters connected therewith or incidental thereto," 22

The Bonded Labor System (Abolition) Rules, 1995 entail the constitution of vigilance committees. The Vigilance Committees are headed by the District Nazim and consist of elected representatives of the area, representatives of the district administration, Bar Associations, Press, Recognized social service and Labor Department of the Federal and Provincial Governments. The functions of the Vigilance Committee as explained in Section 15 of the Act are as under:

(a) to advise the District Administration on matters relating to effective implementation of the law and to ensure its implementation in a proper manner,

(b) to belp in rebabilitation of the freed bonded laborers,

\footnotetext{
${ }^{22}$ Preamble of the Bonded Labor System (Abolition) Act, 1992.
} 
(c) to keep an eye on the working of the law; and

(d) to provide the bonded laborer such assistance as may be necessary to achieve the objectives of the law.

The Rules (4) also provide for the establishment of a free bonded labor Rehabilitation Fund to finance the projects connected with the training of the workers, to provide legal and financial assistance to the freed bonded laborer, and to extend welfare measures for the bonded labor.

\subsection{Labor Laws Applicable to the Brick Kilns}

The major labor laws applicable to brick kilns indirectly relevant to the issue of bonded labor are as under:

i) Factories Act 1934; the law relating to working conditions and health and safety of the workers at the workplace.

ii) Minimum Wages Ordinance; dealing with the fixation and implementation of minimum wages for different categories of skilled and semi-skilled workers including the brick kiln workers.

iii) Payment of Wages Act 1936; deals with the payment of wages, time period of payment and mode of payment of wages to the workers.

iv) Industrial \& Commercial Establishments (Standing Orders) Ordinance 1968; relates to terms of employment, bonus, gratuity and group insurance of the employees.

v) Workmen Compensation Act 1923; relates to payment of compensation to the workers in case of injury or death.

vi) Industrial Relations Ordinance 2002; deals with registration of trade unions, CBA, collective bargaining, conciliation and labor judiciary.

vii) Employment of Children Act 1991; regulates the employment of children in the factories and brick kilns.

viii) Employees Social Security Ordinance which provides medical coverage to the workers. 
ix) Employees Old Age Benefits Act which deals with old age pension.

\subsection{Implementation Status of the Laws Applicable to the Brick Kilns}

The Bonded Labor System (Abolition) Act 1992 is a special law to deal with the issue of bonded labor. Home Departments in the provinces with the help of the district governments are responsible for the administration of the law. The law at the district level is implemented through District Vigilance Committees. The committees are represented by concerned government functionaries, representatives of the bar, Press, NGOs, employers and workers at the district level (Annexed-A). Ironically Vigilance Committees have not been notified in most of the districts. These committees are practically non functional even where notified. The performance of the Committees can be gauged from the fact that not a single case of bonded labor has been detected in any district ${ }^{23}$. Only those few cases of bonded labor however are highlighted in the Press, where High Courts or the Supreme Court take direct action. The Human Rights Commission of Pakistan identified that there was no evidence of a decrease in the bonded labor problem across the country, and the Bonded Labor System (Abolition) Act, 1992 as such remained largely un-enforced during the year 2004. Likewise, no rehabilitation effort as required under Rule (4) has been initiated by any of the districts so far. The National Fund created by the Federal Government for rehabilitation, awareness raising and for education of the children of the brick kiln workers has also not been utilized in any of the districts.

By contrast, the situation in nearby India is quite encouraging. As pointed out by the ILO, up to March 1999, 290,340 bonded labor were identified, amongst these 243,375 had been released and rehabilitated, 20,000 had either died or migrated to other places and 17,000 were in the process of rehabilitation. Action in India has often been taken under the Bonded Labor System (Abolition) Act, 1976 and Supreme Court directives. Yet the difficulty of collecting reliable statistics of bonded labor has been openly recognized by the Government of India ${ }^{24}$.

Minimum Wages Ordinance, 1961 is the other major law applicable to the brick kilns. Under the law, minimum wage rates for the skilled and

${ }^{23}$ This does not imply that advances are not accepted and bonded labor is not exploited at the brick kiln.

${ }^{24}$ Please see Stopping Forced Labor; Global Report under the Follow-up to the ILO Declaration on Fundamental Principle and Rights at Work, ILO Conference 89th Session $200 \mathrm{I}$. 
semi-skilled $^{25}$ workers of different categories are fixed by the Provincial Governments through their respective Minimum Wages Boards. Responsibility of implementation of these minimum rates lies with the Provincial Labor Department. The rates so fixed for the making of 1000 bricks are reflected in Table-1.

\section{Table-1: Fixation of Minimum Wages for the Brick Kilns Labor (PATHERAS)}

\begin{tabular}{cc}
\hline Year & \multicolumn{1}{c}{ Minimum Wage } \\
\hline 1995 & Rs. 125/- Per Thousand Bricks \\
1998 & Rs. 143/- Per Thousand Bricks \\
2002 & Rs. 184/- Per Thousand Bricks ${ }^{26}$ \\
\hline
\end{tabular}

Source: Punjab Minimum Wages Board

Details of the performance under Factories Act 1934, Payment of Wages Act 1936, Industrial and Commercial Establishments (Standing Orders) Ordinance 1969 and Minimum Wages Ordinance during the year 1999 to 2002 in the Province of Punjab is shown in Table-2.

Table-2: Performance of Inspection Machinery of the Directorate of Labor Welfare Punjab on the Implementation of Various Labor Laws Applicable to Brick Kilns

\begin{tabular}{ccccc}
\hline Year & $\begin{array}{c}\text { No. of registered } \\
\text { Brick kilns }\end{array}$ & $\begin{array}{c}\text { No. of } \\
\text { Inspections }\end{array}$ & $\begin{array}{c}\text { No. of } \\
\text { prosecutions }\end{array}$ & $\begin{array}{c}\text { Fine (in } \\
\text { millions) }\end{array}$ \\
\hline 1999 & 495 & 498 & 4375 & 0.098 \\
2000 & 575 & 572 & 5450 & 0.112 \\
2001 & 692 & 693 & 6605 & 0.133 \\
2002 & 926 & 728 & 5756 & 0.164 \\
\hline
\end{tabular}

Source: Directorate of Labor Welfare Punjab.

${ }^{25}$ Brick kiln workers fall in the category of semi-skilled workers.

${ }^{26}$ The bricks for the purpose of remuneration have been categorized for the first time and separate rates for each category have been fixed; i.e. Rs.184 per thousand for ordinary bricks, Rs.218 per thousand for special bricks and Gutaka bricks and Rs. 46 per thousand were fixed for Tiles. 
The Table highlights inspection figures of inspection carried out by the field formation of the Directorate of Labor Welfare Punjab under various labor laws applied to the brick kilns. Inspections as well as prosecutions do not reflect a healthy performance by the field offices. The number of inspections during the year 2002 was less than the total brick kilns registered. Registration of kilns under the Factories Act is also not satisfactory.

Remoteness, lack of transportation, lack of protection of the inspection staff and traditional labor management relations in the industry are the most commonly cited reasons for this slackness. The situation has been further aggravated with the launching of the New Industrial Policy by the Government of the Punjab during the year 2003, under which inspections under various labor laws have been withheld since July $2003^{27}$. The deterrence of inspection, therefore, has been eliminated ${ }^{28}$ and the brick kiln workers are left at the mercy of the owners and the contractors. Similarly, coverage of Employees O1d Age Benefits Act and Employees Social Security Ordinance for the brick kiln workers is also very limited.

\subsection{Limitations of the Law}

The Bonded Labor System (Abolition) Act 1992, a special law to deal with the bonded labor situation, has two weaknesses. Firstly, the law is criticized on the ground that it is a replica of the Indian Act. Secondly, it involves various governmental and non governmental agencies to act and interact on the platform of the Vigilance Committees at the district level which in practice seems very difficult. This is probably the most critical reason for non-implementation of the law.

The Factories Act 1934 is the basic law applicable to premises employing 10 or more workers involved in manufacturing. Implementation of the law in the brick kiln industry has always been debatable. For instance, no premises of brick kilns meet with the requirements of Section- 33 read with Rule-95(1) of the Punjab Factories Rule, 1978. Secondly, it is hard to define the premises as the making of raw bricks shifts from one place to another, depending upon the quality of land and ancillary factors. Thirdly, due to

\footnotetext{
${ }^{27}$ Under the Policy all labor inspections of factories have been stopped and declaration forms have been introduced. All occupiers covered under the policy are required to submit declaration forms once a year. The inspection is carried out through the District Human Resource Board (5 \%) on submission of the declaration by all occupiers. The Policy has been a failure and the workers are being affected seriously.

${ }^{28}$ It is through this deterrence that most of the problems of the workers regarding payment of wages, less payment, delayed payment, non payment, working conditions, and employment conditions were resolved on the spot through simple interference of the functionary.
} 
weather conditions and the nature of the job the working hours of those workers cannot be calculated as required under the law. Fourthly, migratory workers complicate the situation further and create difficulties in the implementation of the law. Due to these difficulties the registration of 1112 brick kilns by the Province of Punjab by 31st August 2005 could not bring about the desired results and brick kiln workers continue to be deprived of the benefits accrued from the schemes of the Workers Welfare Board ${ }^{29}$.

The Minimum Wage Ordinance has its own problems; the minimum rates fixed under the law do not suit all the areas due to variation in the cost of living, quality of bricks and price of the bricks. The minimum wage rates should be made more realistic by taking into account all such factors. Different rates can be fixed for different regions in the same province. Minimum wages should be fixed after in depth research and keeping in view the basic needs of the brick kiln workers ${ }^{30}$. Non maintenance of records and the informal mode of payment of wages, on the other hand, make the implementation of Payment of Wages Act more difficult.

The Employment of Children Act 1991 is also not applied to families engaging their children in brick-making. Health facilities of Social Security Scheme, pension of Employees Old Age Benefit Act and the welfare schemes of the Workers Welfare Board have limited scope as far as the brick kiln workers are concerned.

The preceding analysis indicates that the laws are not only complicated, but that some of them also do not correspond with the traditional model of labor relations prevailing in the brick kilns. Inspection machinery is also handicapped, particularly after the recent political devolution and introduction of the New Industrial Policy of the provincial government.

\section{Trade Unions and Bonded Labor}

It is argued that trade unions by creating awareness among their members about the severe effects of advances could be torch bearers in highlighting the issue of bonded labor. Such a role can only be possible by

\footnotetext{
${ }^{29}$ It is practically difficult to implement the law at the brick kilns. That is why the registration of brick kilns under the Factories Act could not yield the desired results. Brick kiln workers have not been recognized and owned by the occupier (owner) as workers. The workers resultantly could not obtain benefits from the schemes of Workers Welfare Board enjoyed by their fellow workers in the factories.

${ }^{30}$ The food basket approach involves basic necessities of the workers, his cost of living, average family size, inflation etc. Although it is time consuming and requires a lot of research before the wages are actually fixed, it is the most realistic approach for the fixation of minimum wages.
} 
the unions if they are strong, democratic and represented by the workers at the grassroot level. Unfortunately, trade unions in the brick kiln sector are weak, fragmented, and have no footing at the workplace. The labor movement lacks genuine leadership. There are only three trade unions in the brick kiln sector which are registered at the provincial level and their membership does not even exceed $333^{31}$. The labor organizations are managed either by contractors or some ex- brick kiln workers. Unions are more common at the brick kilns near Lahore, have the recognition of the employer and bargain for working conditions and implementation of minimum wage notifications (Mitha et. al., 1998). According to them, trade union activities are restricted to male workers, and only four women were found as office bearers of the union ${ }^{32}$.

Trade unions have played a very limited role as far as the issue of bonded labor is concerned. The Brick Kilns Owners Associations are more organized and effective than the labor organizations. There is a strong need for sensitizing the mainstream labor movement over the issue of bonded labor. They should also mobilize their allies in the brick kiln sector with the assurance that without strong labor organizations the suffering of bonded labor could neither be highlighted nor addressed. As advocated by Ercelawn (2002) 'whatever Government does by way of improving the situation of bonded labor, success will come largely through mobilization of labor. The government is required to remove all legal and administrative hurdles to the formation of labor associations and collective bargaining, as required by the ILO core conventions' (Ercelawn and Ali, 2002).

\section{Role of NGOs}

The efforts of NGOs in addressing the issue of bonded labor have been significant. The Bonded Labor Liberation Front (BLLF) with the help of the Human Rights Commission of Pakistan launched rallies, seminars and symposia to create awareness by highlighting the atrocities of bonded labor during the late 80s. Both also coordinated in fighting a legal battle that went to the Supreme Court of Pakistan. BLLF was instrumental in pressuring the government to promulgate the Bonded Labor System (Abolition) Act 1992. The BLLF also ran around 200 Apna Schools for the children of the brick kiln workers $^{33}$. The spade work of the BLLF made the task easier for late comers such as PILER and the Human Rights Commission of Pakistan. At present a

\footnotetext{
${ }^{31}$ Directorate of Labor Welfare, Punjab.

${ }^{32}$ See Mitah et. al.; Solid Foundations Solid Contributions, Women in the Brick Kiln Industry ASR, Lahore.

${ }^{33}$ BLLF leader Ahsanullah was very popular amongst the brick kiln workers during the early 90s. The NGO could not gain that momentum after its leader left for Switzerland.
} 
few NGOs can be found working in the field of bonded labor. However, it is difficult to find any in the brick kiln sector.

\section{Recommendations}

The foregoing analysis highlights that a number of agencies are involved in the efforts for the eradication of bonded labor from the brick kiln sector. All work in isolation of each other; the role of trade unions is negligible, NGOs need more involvement and the working of government departments, such as Labor, Home Department, Police, Social Security, Employees Old Age Institutions etc. need redirection, overhauling and strengthening.

The complexity of the issue and its socio-economic repercussions imply that no single strategy can address the issue extensively. Compartmentalization of the issue may lead to chaos in the end. It is only through a comprehensive plan of action, and multi- pronged strategy that the menace of bonded labor can be eradicated. The plan must be a model focusing simultaneously on all aspects of bonded labor. It should involve economic recovery, through increase in real wages, micro credit, independence from advances / loans and clutches of the owner, extension of Workers Welfare Board schemes to the brick kiln workers, Social Security Coverage, medical coverage, pension coverage under Employees Old Age Benefits Act; educational breakthrough, through free and compulsory elementary education to the children of the brick kiln workers. It should include training during off season, technical and vocational training of the children of the brick kiln workers, special emphasis on female education, adult education programs, and informal education; social uplift, through community organization and development, enhanced social motivation, promotion of workers participation in local governance, organizing trade unions and owners associations, general awareness about rites and customs and the negative effects of advances, etc.

The brick kilns are usually located in clusters. The district governments within their district limits should require formal notification for the establishment of brick kilns. Brick kilns should only be allowed to be established in clusters. A cluster should have a reasonable number of brick kilns (20-25) and be like an industrial estate. Keeping in view the migratory nature of the business, the government should also decide where the cluster has to move after ten years when most of the suitable soil will be utilized and no soil will be available in the nearby area. There should be an independent authority in the district at each cluster, handling all the affairs, i.e., technical, administrative, financial, legal, and educational issues relating to labor and 
socio-cultural development. Representatives of all inline departments such as police, labor, health, education, banks, and infrastructure development etc., should be at the disposal of the authority. One Window facility at each cluster should be provided to both the owners as well as to the workers and their families. The issue of advances will automatically be resolved with the implementation of the scheme because in the presence of all the relevant government functionaries, NGOs and representatives of civil society, it would be hard for the system to prevail. All labor laws, particularly laws relating to monitory benefits for the workers such as Minimum Wage, Payment of Wages Act, Social Security Laws, EOBI, and Workers Welfare Schemes of Workers Welfare Board and Bonded Labor System (Abolition) Act should be consolidated into a single enactment meant exclusively for the brick kilns. The real wages and the income of the workers would be rationalized through effective implementation of the law. Micro credit should be available through scheduled banks at their door steps. Free and compulsory basic education should be provided at each cluster and the children of the brick kiln workers should be provided technical, vocational, and higher education in the nearby educational institutions of the Workers Welfare Board, TEVTA and education department free of cost. The community should be mobilized through organizing owners and workers. Special Career Counseling should be offered to the workers, their children and the owners as well. Apparently, the plan looks overambitious but in reality no additional funds are required to implement the plan. Rather, the plan will require the reorganization and streamlining of various governmental and non governmental agencies already working in the field by the pooling of resources, accurate management and extending educational, health, training, pension and banking facilities for the bonded labor. Only in this way can the conditions of bonded families be improved.

\section{Conclusion}

Bonded labor is a dominant feature of the brick kiln industry of Pakistan. The bondage forfeits the workers' right to move freely and sell their labor. The clutches of bondage involve physical, economic and psychological exploitation of the bonded families. The implementation of the Bonded Labor law met with great criticism. Rehabilitation efforts lack coordination and special efforts therefore are required on the part of all concerned working in the field of bonded labor. The proposed model provides a blueprint for the streamlining, consolidation and coordination of efforts in the right direction with an overall objective of the eradication of bonded labor from the brick kiln sector. 
ANNEXURE-A

\section{Office of the District Coordination Officer, Faisalabad}

\section{ORDER}

In pursuance of Home Department's letter No SO(Jud1-11)2-13/(P-4), dated 6.9.2001 and 20.8.2002, the District Nazim Faisalabad has been pleased to constitute the District Vigilance Committee under Rule -6 of Bonded Labor System (Abolition) Rules 1995, consisting of the following members:

\begin{tabular}{|c|c|c|}
\hline $\begin{array}{l}\text { Sr. } \\
\text { No. }\end{array}$ & Name of Member & $\begin{array}{l}\text { Designation of } \\
\text { the Committee }\end{array}$ \\
\hline & District Nazim & Chairman \\
\hline & District Coordination Officer & Member \\
\hline & District Police Officer & Member \\
\hline & President District Bar Association & Member \\
\hline & District Officer Labor & Member/Secretary \\
\hline & District Officer Education Elementary & Member \\
\hline & District Officer Agriculture Extension & Member \\
\hline & District Officer Health & Member \\
\hline & District Officer Social Welfare & Member \\
\hline & $\begin{array}{l}\text { Dr. Bashir Ahmad Chaudary, President Mother and } \\
\text { Child Welfare Association }\end{array}$ & Member \\
\hline & Seth Abdul Hamid President Brick Kilns Association & Member \\
\hline & Mr. Ghulam Farid Fateh Workers Union, Nishat Mills, Faisalabad & Member \\
\hline & $\begin{array}{l}\text { Mrs. Hamid Saeed, All Pakistan Women Association, } \\
720-P \text {, Batala Colony, Faisalabad }\end{array}$ & Member \\
\hline 14. & Mr. Shahid Baig Member District Assembly & Member \\
\hline & Mr. Kamal Nazami Journalist, Daily Nawa-i-Waqat & Member \\
\hline 16. & Ch. Muhammad Tai Retired District and Session Judge & Member \\
\hline & Mr. Abdu1 Wahid Butt, Anjaman-i-Islamia, Tariqabad & Member \\
\hline & Mr. Tasawar Hussain Naqvi, Director SOS. & Member \\
\hline
\end{tabular}

The District Vigilance Committee will perform and achieve the objectives as laid down under Section 15 of the Bonded Labor System (Abolition) Act 1992 and Rule 7, 8, 9 of the Bonded Labor System (Abolition) Rules 1995.

By Order of the District Nazim Faisalabad

No. 3(100)/SG/DCO/381 - 400

Dated: $21-1-2003$

A copy is forwarded to:

1. The Under Secretary (Jud-II), Government of the Punjab, Home Department, Lahore.

2. All the members of the Committee.

3. The PSO to District Nazim Faisalabad. 


\section{References}

Bales, Kevin, 1998, Disposable People, New Slavery in the Global Economy, University of California Press Berkeley / Los Angeles / London.

Ercelawn, A. and A. Karamat, 2002, Bonded Labor in Pakistan: Impacts of Policy, Law and Economy, The Journal, NIPA, Karachi, March 2002, Vol. 7, No. 1.

Ercelawn, A. and Nauman M., 2002, Bonded labor in Pakistan: An Overview A Study for ILO, by Pakistan Institute of Labor Education and Research, Karachi, The Journal, NIPA Karachi, March 2002, Vo1. 7, No. 1.

Government of Pakistan, 1934, Factories Act.

Government of Pakistan, 1936, Payment of Wages Act.

Government of Pakistan, 1961, Minimum Wage Ordinance.

Government of Pakistan, 1968, West Pakistan Industrial and Commercial Establishments (Standing Orders) Ordinance.

Government of Pakistan, 2002, Industrial Relations Ordinance.

Government of Pakistan, 2002, Labor Policy.

Government of Pakistan, 1992, Bonded Labor System (Abolition) Act.

Government of Pakistan, 1995, Bonded Labor System (Abolition) Rules.

Government of the Punjab, 1995, 1998, 2002, Notifications for Skilled and Unskilled Workers by the Punjab Minimum Wages Board.

Government of the Punjab, 2002, Performance under Various Labor Laws applicable to Brick Kilns and Details of registered Brick Kilns: Annual Reports.

Hamid, A. Narmeen, 1993, Health and Industrial Status of Working Children in Brick Kilns, Carpet Weaving Industry and Garages, A medical study conducted in Lahore and in collaboration with the Islamic Welfare Society, Lahore and UNICEF. 
Human Rights Commission of Pakistan, 2001 and 2004, State of Human Rights, published by Human Rights Commission of Pakistan, Lahore.

Hussain, Akmal, 1990, Child Workers in Construction and Related Industries in Pakistan: Paper submitted to ILO, Geneva.

ILO, 2004, Rapid Assessment Studies of Bonded Labor in Different Sectors; Ministry of Labor, Manpower and Overseas Pakistanis.

ILO, 1998, Child Labor in the Brick Kilns: District Sialkot, A Survey Report. The Survey was conducted as a part of an International Program on the Elimination of Child Labor (IPEC) by Labor and Manpower Department Government of the Punjab.

ILO, 2001, Stopping Forced Labor; Global Report under the Follow-up to ILO Declaration on Fundamental Principles and Rights at Work.

Mitha, Y. Anwar, M. Said Nighat, Javed, A., 1989, Solid Foundations Solid Contributions; Women in the Brick Kiln Industry, ASR, Lahore.

Thomas, Henk, (Ed), 1995, Globalization and Third World Trade Unions: The Challenges of Rapid Economic Change; Zed Books London and New Jersey. 